\title{
Neoplastic patients' knowledge about intestinal parasitoses in southern Brazil
}

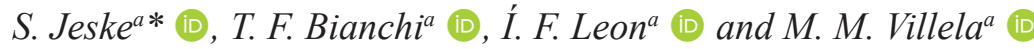 \\ aPrograma de Pós-graduação em Parasitologia, Departamento de Microbiologia e Parasitologia, Instituto de Biologia, \\ Universidade Federal de Pelotas - UFPel, Campus Universitário, Av. Eliseu Maciel, s/n, CEP 96160-000, \\ Capão do Leão, RS, Brasil \\ *e-mail: sabrinajeske@hotmail.com
}

Received: August 13, 2018 - Accepted: January 25, 2019 - Distributed: May 31, 2020

\begin{abstract}
Since oncologic patients have been considered an important risk group for parasitic infections, it is fundamental to find out what they know about intestinal parasites. This study aimed at evaluating knowledge that the adult oncologic patients undergoing chemotherapy in the main centers of treatment for cancer in the city of Pelotas, Brazil, has about intestinal parasites. A semi-structured questionnaire was used for collecting data from two hundred oncologic patients who were undergoing chemotherapy. Results showed that $69.5 \%$ know what intestinal parasites are and cited Ascaris lumbricoides and Taenia sp. as being the most known ones. The statistical comparison between the group that knows intestinal parasites and the one that does not know about them - associated with socioeconomic variables -, showed that factors that significantly influenced their knowledge were their place of residence, schooling and household income $(\mathrm{p} \leq 0.05)$. Only $36 \%$ stated that they know when they are infected with parasites and misdescribed some signs and symptoms. Regarding prevention, $52 \%$ mentioned that they do not know how to avoid parasitism. The population under study showed that there are some gaps in its knowledge of the theme under investigation. Therefore, it is important to implement socioeducational measures in hospitals and clinics that treat cancer patients.
\end{abstract}

Keywords: knowledge, verminoses, cancer, immunocompromised patients.

\section{Conhecimento de pacientes neoplásicos sobre parasitoses intestinais no sul do Brasil}

\section{Resumo}

Pacientes oncológicos são considerados um importante grupo de risco para infecções parasitárias, logo, é fundamental conhecer o que sabem sobre parasitos intestinais. O objetivo deste estudo foi avaliar os conhecimentos de indivíduos oncológicos adultos submetidos à quimioterapia nos principais centros de tratamento para o câncer no município de Pelotas, RS, sobre as enteroparasitoses. O instrumento utilizado para coleta dos dados foi um questionário semiestruturado. Foram incluídos nesta pesquisa 200 pacientes oncológicos submetidos à quimioterapia. Destes, $69,5 \%$ sabem o que são parasitos intestinais, citando Ascaris lumbricoides e Taenia sp. como os mais conhecidos. Quando realizada a comparação estatística do grupo que conhece parasitos intestinais/vermes com o grupo dos que desconhecem o tema, associadas com variáveis socioeconômicas, foi verificado que a zona em que residiam, a escolaridade e a renda familiar são fatores que influenciam no conhecimento dos indivíduos de forma significativa $(\mathrm{p} \leq 0,05)$. Apenas $36 \%$ dos indivíduos afirmaram saber quando estão parasitados, relatando alguns sinais e sintomas equivocadamente. Relacionado à prevenção, $52 \%$ mencionaram não saber como evitar o parasitismo. A população estudada possui lacunas no conhecimento sobre o tema abordado e, por isso, é importante a realização de ações socioeducativas junto aos hospitais e clínicas de tratamento dos pacientes com câncer.

Palavras-chave: conhecimentos, verminoses, câncer, pacientes imunocomprometidos.

\section{Introduction}

Intestinal parasitoses have been an important public health issue since they contribute to human morbidity and mortality rates worldwide, mainly in developing countries (Brooker et al., 2015; Forson et al., 2018). The following are usually considered risk factors for contracting parasites: inappropriate sanitary installations, water and food contamination, sociocultural and socioeconomic influences, contact with animals and characteristics that are inherent to hosts and parasites (Vidal et al., 2010; Wright, 2012; Curi et al., 2016). 
The process of contracting parasites and the severity of the parasitic infection depend on the host's immunologic status (Azami et al., 2010); thus, oncologic patients have been considered an important risk group for this infection, since both cytotoxic chemotherapy and radiotherapy - used for treating cancer patients - harm their defense mechanisms, which have often also been affected by the disease (Vento and Cainelli, 2003; Pacheco et al., 2014). Therefore, individuals who have undergone immunosuppressive therapy are likely to contract infectious agents. Besides, the disease is usually more severe in these patients, mainly when it is caused by opportunistic parasites (Albuquerque et al., 2012; Rossi and Couturier, 2016).

Studies carried out in Pelotas, Rio Grande do Sul (RS) state, Brazil, with oncologic patients, showed that there was high prevalence of intestinal parasites (Jeske et al., 2018) and that these individuals were considered a risk group for enteroparasitic infections (Marcos and Gotuzzo, 2013; Gupta et al., 2013; Barros and Montes, 2014). As a result, it is fundamental to investigate how much they know about the theme, since information collected by this process is essential to implement action plans and intervention programs (Mello et al., 1988; Pedrazzani et al., 1990; Carvalho and Malafaia, 2016). Taking into account the relevance of this topic, this study aimed at evaluating oncologic patients' knowledge of intestinal parasitoses/verminoses.

\section{Methodology}

\subsection{Study area and population}

A descriptive study with qualitative and quantitative approach, carried out at the Centro Regional de Oncologia/Radioterapia (CRO), situated at the Faculdade de Medicina of the Universidade Federal de Pelotas (UFPel), the Hospital Clinicanp and the Clínica de Radioterapia e Oncologia (CERON), from 2013 to 2017. They are all reference centers in cancer treatment in Pelotas, a city located in the south of RS, Brazil ( $31^{\circ} 46^{\prime} 19^{\prime}$ ' S and $\left.52^{\circ} 20^{\prime} 34^{\prime \prime} \mathrm{W}\right)$. This approach reflects the reality of oncologic patients in the south of RS since individuals from 22 cities are assisted by these health services, which have been considered references in the extreme south of Brazil.

The study population consisted of adult oncologic patients who were submitted to chemotherapy in the treatment centers addressed. The objectives of the study were explained to them and the ones who voluntarily agreed to take part in it signed an Informed Consent (IC) form. The project was approved by the Research Ethics Committee at the UFPel (Protocol n ${ }^{\circ} 1,618.312$ ).

\subsection{Study instrument}

The instrument that was applied by the study was a semi-structured questionnaire with both open-ended questions (with no alternatives) and closed-ended ones which addressed socioeconomic issues and knowledge the population had of intestinal parasitoses/verminoses. Its first section collected patients' demographic and socioeconomic data, whereas the section that aimed at investigating their knowledge on intestinal parasitoses was composed of the following questions:"1. Do you know anything about parasites or intestinal parasitoses/verminoses?"; "1.1.IF SO, which do you know/have you heard about?; "2. Where have you learned/heard about parasites?"; "3. Have you ever seen any parasite? (1)yes (2)no"; "3.1. IF SO, where/when?”; "4. Do you know/feel when you have intestinal parasites? (1)yes (2)no"; "5. What does a person who is infected with parasites feel when she has intestinal parasites?"; "6. Does verminoses cause any harm or problem to people?”; “6.1. IF SO, which one(s)?”; "7. Do you know how not to contract intestinal parasites?"; "7.1. IF SO, how?"; "8. Have you already taken any medication to treatany verminosis?"; "8.1. IF SO, how long ago did you take the latest one?"; "8.2. How often do you take this medication?"; "9. Have you ever been infected with any parasite?"; "9.1. IF SO, which one?"; "9.2. Before or during the chemotherapy treatment?"; "9.3. Did you treat it with any medicine? (1)yes (2)no"; "9.4. IF SO, which one?"; "9.5. IF NOT, why not?". The final questions of the questionnaire were related to the diagnosis of the disease and information on the patient's health.

\subsection{Educational material}

An educational booklet was made and distributed to the study participants, health professionals, hospital staff and visitors. It addressed the main intestinal parasitoses that are found in the region and measures that should be taken to avoid them. The booklet had illustrations and information on parasites which had been diagnosed by the latest studies that were carried out in the region (Almeida et al., 2017; Jeske et al., 2018).

\subsection{Data statistical analysis}

Firstly, a descriptive comparison among groups for every variable was carried out and values were expressed as frequencies (value found in the sample - $n$ ) and as percentages (\%). All data were compiled by the Microsoft Office Excel ${ }^{\circledR} 2010$. Statistical significance among groups (the ones who know about intestinal parasites and the ones who do not) and variables under study were analyzed by the chi-squared test $\left(\chi^{2}\right)$ with the use of the MINITAB $18^{\circledR}$ software and the Odds Ratio. Variables were considered significant when $\mathrm{p} \leq 0.05$.

\section{Results}

This study comprised 200 oncologic patients who were between 18 and 89 years old. They had been referred to chemotherapy treatment due to distinct diagnoses, mainly breast (36\%) and intestine (24\%) cancer.

Questionnaires showed that 69.5\% (139 individuals) answered that they did not know what intestinal parasites were. When the statistical comparison between the group that knows what intestinal parasites are with the one that does not know about the topic was conducted, and socioeconomic variables were associated, the study found out that the region where they live (urban area; $p<0.0001$ ), schooling ( 10 years or more; $\mathrm{p}=0.0012$ ) and household 
income (above a minimum salary; $\mathrm{p}<0.0001$ ) were factors that influenced individuals' knowledge positively, as shown in Table 1. Other socioeconomic variables were tested but were not statistically significant.

Regarding to the question on which the parasites that the subjects knew, the most cited ones were Ascaris lumbricoides (51.1\%) and Taenia sp. (37.4\%), which were identified by their common names in Portuguese. Other parasites were also mentioned: Giardia lamblia $(6.5 \%)$, Entamoeba spp. (2.9\%) and Enterobius vermicularis $(2.1 \%)$. Most participants said that they had learned about parasites at home, on TV, in texts, in internet, with their children, or had already been infected with some of these organisms. Few participants also mentioned their schools, colleges, veterinarians and health centers.

When they were asked whether they had already seen any parasite, $58 \%$ (116) answered that they had seen it in either their own or their family members' feces $(83.6 \%)$ whereas $8.6 \%$ said they had seen it when family members had expelled it through the mouth (vomit) or the nose and $7.8 \%$ had seen parasites in a laboratory, hospital or health center.

Only $36 \%$ (72) of participants stated that they knew when they were infected with parasites. Concerning signs and symptoms generated by intestinal parasitoses, the most cited ones were cramps, abdominal pain, "pain in the belly" and itching. Other symptoms, such as queasiness, body pain, mouth ulcers, diarrhea, dizziness, swollen belly, blood in stool, paleness, increased appetite, teeth grinding and sugar cravings.

When participants were asked whether parasitism caused some harm to the host, most (71.5\%) answered that they were aware of it, whereas $26.5 \%$ did not know and $2 \%$ said that it causes no harm to infected persons. Regarding the harm, 98 patients (49\%) answered that they did not know which harm it caused, $23 \%$ said that much harm is caused and $28 \%$ cited disorders, such as anemia, weight loss, diarrhea, malnutrition, mental retardation and organ perforation and obstruction.

Concerning prevention, 52\% (104 patients) answered that they did not know how to avoid intestinal parasites. Prevention measures cited by the ones who knew how to avoid those ( $48 \%$ or 96 individuals) were personal hygiene and food hygiene (80.2\%).

When they were asked whether they had already taken any medicine against parasites, 55\% (110 patients) confirmed it, while $40 \%$ (80 patients) said that they had never taken any and 5\% (10 patients) did not answer the question. Fourteen persons (12.7\%), out of the ones who have already taken some anti-parasitic medicine, have done it for a year or less.

Regarding the question "Have you ever been infected with any parasite?", 60.5\% (121 individuals) answered yes. Most (93.4\%) of them said that they had had parasitism before they underwent chemotherapy whereas $5 \%$ reported that the infection had occurred during the treatment and $1.6 \%$ had been infected before and during the chemotherapy treatment. When they were asked which parasite had infected them, Ascaris lumbricoides was the most cited one (48.8\%), but others were also mentioned Giardia sp., Taenia sp., Entamoeba sp., Enterobius vermicularis and some referred to "very little parasites". Taking into account 121 participants who had already been infected, $58.7 \%$ underwent treatment, $32.2 \%$ did not undergo any and $9.1 \%$

Table 1. Association between socioeconomic variables and groups (what knows about intestinal parasites and what does not know about the subject) of cancer patients submitted to chemotherapy treatment in southern Brazil $(n=200)$.

\begin{tabular}{|c|c|c|c|c|}
\hline \multirow[b]{2}{*}{ Socioeconomic variables } & \multicolumn{2}{|c|}{ GROUPS } & \multirow[b]{2}{*}{$p$ value } & \multirow[b]{2}{*}{ Odds Ratio (CI*) } \\
\hline & $\begin{array}{c}\text { Know about } \\
\text { intestinal } \\
\text { parasites } \\
(n=139)\end{array}$ & $\begin{array}{l}\text { Does not know } \\
\quad(n=61)\end{array}$ & & \\
\hline Age group & $n(\%)$ & $n(\%)$ & 0.2066 & $1.52(0.7944-2.8995)$ \\
\hline $18-50$ & $54(75 \%)$ & $18(55 \%)$ & & \\
\hline $51-89$ & $85(66.4 \%)$ & $43(33.6 \%)$ & & \\
\hline Gender & & & 0.5954 & $1.18(0.6337-2.2152)$ \\
\hline Female & $92(70.8 \%)$ & $38(29.2 \%)$ & & \\
\hline Male & $47(67.1 \%)$ & $23(32.9 \%)$ & & \\
\hline Area that resides & & & $<0.0001$ & $8.53(4.1851-17.3755)$ \\
\hline Urban & $97(88.2 \%)$ & $13(11.8 \%)$ & & \\
\hline Rural & $42(46.7 \%)$ & $48(53.3 \%)$ & & \\
\hline Schooling & & & 0.0012 & $11.09(2.5834-47.6846)$ \\
\hline 10 years or more of study & $38(95 \%)$ & $2(5 \%)$ & & \\
\hline Up to 9 years of study & $101(63.1 \%)$ & $59(36.9 \%)$ & & \\
\hline Family income & & & $<0.0001$ & $24.44(10.8924-54.8267)$ \\
\hline Above a minimum salary** & $115(92 \%)$ & $10(8 \%)$ & & \\
\hline Up to 1 minimum wage** & $24(32 \%)$ & $51(68 \%)$ & & \\
\hline
\end{tabular}

*95\% Confidence Interval; **Minimum wage in Brazil = R \$ 954.00 (approximately US \$250.00 in December 2018). 
did not remember/know whether they had undergone any treatment. The ones who did not undergo any treatment said that this fact was due to their condition of poverty and because they had no access to health services, which were very far from their homes. Concerning the type of treatment, $76 \%$ did not remember the drugs they had taken, $14 \%$ cited anti-parasitic drugs whose active ingredients are albendazole, levamisole hydrochloride and nitazoxanide and $9.9 \%$ reported that they had chosen home remedies, such as oil purgative, cocoa liqueur and faith healing.

\section{Discussion}

Since parasitic infections are emergent and potentially severe in their evolution, mainly in immunosuppressed patients, i. e., the number of infected individuals has increased, even the one of patients who contract them in hospitals, it is necessary to find out what they know about these diseases so as to implement preventive measures (Góralska and Kurnatowski, 2013; Jeske et al., 2018).

Considering the participants in this investigation, $69.5 \%$ know intestinal parasites and their common names. The most cited ones, Ascaris lumbricoides and Taenia sp., were also the most often mentioned ones by other studies (Moraes Neto et al., 2010; Silva and Leda, 2013; Siqueira et al., 2016). Ascaris lumbricoides has become popular because this parasite is common in developing countries. Besides, it can be expelled and is visible to the naked eye, a fact that makes it identification easier (Moraes Neto et al., 2010). Protozoa were not often mentioned by participants in this study. Likewise, Siqueira et al. (2016) reported that only $2.7 \%$ of their interviewees knew something about these parasites.

The use of common names given to parasites showed that the population has some codes to identify parasites, besides its own conceptualization of signs and symptoms, epidemiologic factors and types of treatment. This information is fundamental to plan educational campaigns and projects which aim at intestinal parasitoses (Mello et al., 1988; Busato et al., 2015; Siqueira et al., 2016). Most participants said that they had learned about intestinal parasitoses/ verminoses when they were watching television, reading, researching in internet and listening to their children. Besides, some had already been infected by some intestinal parasite. Santos et al. (2012) evaluated students' knowledge about intestinal parasitoses and found out that means of communication, such as television and radio, were also their main sources of information on parasitic diseases. Therefore, it should be highlighted that means of communication and media are important to learning processes, since they are tools to both knowledge construction and socialization of information (Moran, 1994; Sanchez and Fairfield, 2003). Children's roles as disseminators of information should also be emphasized (Silva et al., 2011) because many participants said that they had learned about the issue from their schoolchildren.

Although schools had only been mentioned few times as places where interviewees learned about parasitoses/verminoses, the ones with the highest schooling level were 11.09-fold more likely to know intestinal parasitoses $(p=0.0012)$. Association of length of formal education with more knowledge about health, use of appropriate attitudes and decrease in rates of intestinal parasitoses has been observed by researchers in developing countries and has shown the importance of schooling to learning and welfare (Tanner et al., 2011; Greenaway et al., 2012; Ambrozio et al., 2017). The region where the patients lived was also a factor that influenced the population's knowledge, i. e., it was lower among individuals from rural areas. It may be related to their low schooling level and to the fact that they lived in bad conditions of housing and hygiene; thus, they were more susceptible to infection by intestinal parasites (Ludwig et al., 1999; Alves, 2003; Oliveira et al., 2013).

The study reported by this paper also showed that subjects whose income was above a minimum salary were 24.44-fold more prone to have information about enteroparasites and verminoses. This fact is important because, according to Detollenaere et al. (2018), even in continents with high Human Development Index (HDI), such as Europe, low income has clearly been associated with decrease in health and suggests that an efficient primary care system may attenuate this negative association.

Some participants $(36 \%)$ said that they knew when they had been infected and, although they cited some adequate signs and symptoms caused by enteroparasitic infections, they reported some wrong concepts. Among the symptoms which were mistakenly associated with clinical signs and symptomatology, the most cited one was "cravings for sweets", besides teeth grinding and mouth ulcers. Association of intake of sweets with parasitoses has been shown by several authors, even though none has given any explanation for such fact (Siqueira and Fiorini, 1999; Acka et al., 2010; Moraes Neto et al., 2010). However, according to Siqueira et al. (2016), this belief may result from the diarrhea that affects children after they eat a lot of sweets. Since diarrhea also occurs as the result of infections caused by intestinal parasites, parents may culturally internalize the association of enteroparasitoses with cravings for sweets. Another explanation that can be brought up is related to the fact that the main food source of some intestinal helminths, mainly A. lumbricoides, is carbohydrates. It deprives the host of such elements and may make infected individuals look for food which is rich in them, as a metabolic and biochemical answer.

Regarding consequences of parasitism, 98 patients (49\%) answered that they did not know which harm it caused. Therefore, it is an essential topic to be addressed by educational programs since parasitic infections in risk groups, such as oncologic ones, may become important causes of morbidity and mortality (Gabe et al., 2009; Alemu et al., 2011).

Concerning preventive measures, $48 \%$ of interviewees mentioned personal and food hygiene, which were the most cited prophylactic practices. They are fundamental factors in parasitic infection prevention and control, since they 
include basic measures, such as frequent hand washing, nail clipping and bathing, besides washing and protecting food from insects (Olsen et al., 2006; Do et al., 2007). Other preventive measures were rarely mentioned, but they are also important: wearing shoes, for instance. Being barefoot is a risk factor for many infections, mainly in a population that is more susceptible to different pathogens (Lesshafft et al., 2011; Schär et al., 2013; Rivero et al., 2017). In addition, the use of potable water (Amuta et al., 2010) and care towards the origin, preparation and consumption of foods should be highlighted because they are modes of transmission, especially when they are either consumed in natura or undercooked (Nyarango et al., 2008; Dorny et al., 2009).

It is worth emphasizing that, in the group of individuals who had already been infected by some intestinal parasite $(60.5 \%), 32.2 \%$ did not undergo any treatment, whereas, in the group who underwent it (587\%), 9.9\% used home remedies, such as oil purgative, cocoa liqueur and faith healing. This type of treatment was also reported by other studies which identified that the population used teas, medicinal plants, home medicine and superstition, besides seeing faith healers to treat parasitic infections (Mello et al., 1988; Busato et al., 2015; Pio et al., 2018). Infected individuals who did not undergo treatment mentioned their condition of poverty and the fact that they could not pay for the treatment. In addition, they referred to constraints that were also reported by other studies, i. e., difficulty in accessing health services and both lack of transportation to health centers and free drugs in these crowded places (Danso-Appiah et al., 2010; Masaku et al., 2017).

\section{Conclusion}

This study shows that, even though most oncologic patients under study know intestinal parasites and are aware of harm caused by parasitism, there are gaps in their knowledge of intestinal parasitoses, mainly protozoa, issues related to clinical signs and symptoms and prevention.

Some variables, such as schooling, income and place of residence, are factors that influence the knowledge of the population under investigation. The importance of schooling and educational measures to the economically disadvantaged, mainly the rural population, should be emphasized. Therefore, this study shows that socioeducational programs aiming at cancer patients should be implemented in hospitals and clinics so as to inform and clarify doubts about main intestinal parasitoses.

\section{References}

ACKA, C.A., RASO, G., N'GORAN, E.K., TSCHANNEN, A.B., BOGOCH, I.I., SÉRAPHIN, E., TANNER, M., OBRIST, B. and UTZINGER, J., 2010. Parasitic worms: knowledge, attitudes, and practices in western côte d'ivoire with implications for integrated control. PLoS Neglected Tropical Diseases, vol. 4, no. 12, pp. e910. http://dx.doi.org/10.1371/journal.pntd.0000910. PMid:21200423.

ALBUQUERQUE, Y.M.M., SILVA, M.C.F., LIMA, A.L.M.A. and MAGALHÃES, V., 2012. Criptosporidiose pulmonar em paciente com AIDS, uma doença subdiagnosticada. Jornal Brasileiro de Pneumologia, vol. 38, no. 4, pp. 530-532. http:// dx.doi.org/10.1590/S1806-37132012000400017. PMid:22964939.

ALEMU, A., SHIFERAW, Y., GETNET, G., YALEW, A. and ADDIS, Z., 2011. Opportunistic and other intestinal parasites among HIV/AIDS patients attending Gambi higher clinic in Bahir Dar city, North West Ethiopia. Asian Pacific Journal of Tropical Medicine, vol. 4, no. 8, pp. 661-665. http://dx.doi.org/10.1016/ S1995-7645(11)60168-5. PMid:21914548.

ALMEIDA, I.A., JESKE, S., MESEMBURG, M.A., BERNE, M.E.A. and VILLELA, M.M., 2017. Prevalence of and risk factors for intestinal parasite infections in pediatric patients admitted to public hospitals in Southern Brazil. Revista da Sociedade Brasileira de Medicina Tropical, vol. 50, no. 6, pp. 853-856. http://dx.doi. org/10.1590/0037-8682-0116-2017. PMid:29340467.

ALVES, M.F.P., 2003. Sexualidade e prevenção de DST/AIDS: representações sociais de homens rurais de um município da zona da mata pernambucana, Brasil. Cadernos de Saude Publica, vol. 19, no. 2, suppl. 2, pp. 429-439. http://dx.doi.org/10.1590/ S0102-311X2003000800024. PMid:12764458.

AMBROZIO, C.L., BIANCHI, T.F., ARAÚJO, A.C., JESKE, S. and VILLELA, M.M., 2017. Trichomonas vaginalis / Awareness of trichomoniasis in women attended by the health service of Bagé, RS, Brazil. Revista de Patologia Tropical, vol. 46, no. 3, pp. 245-252. http://dx.doi.org/10.5216/rpt.v46i3.49291.

AMUTA, E.U., HOUMSOU, R.S. and MKER, S.D., 2010. Knowledge and risk factors of intestinal parasitic infections among women in Makurdi, Benue State. Asian Pacific Journal of Tropical Medicine, vol. 3, no. 12, pp. 993-996. http://dx.doi. org/10.1016/S1995-7645(11)60016-3.

AZAMI, M., SHARIFI, M., HEJAZI, S.H. and TAZHIBI, M., 2010. Intestinal parasitic infections in renal transplant recipients. The Brazilian Journal of Infectious Diseases, vol. 14, no. 1, pp. 15-18. http://dx.doi.org/10.1016/S1413-8670(10)70004-0. PMid:20428648

BARROS, N. and MONTES, M., 2014. Infection and hyperinfection with Strongyloidesstercoralis: clinical presentation, etiology of disease, and treatment options. Current Tropical Medicine Reports, vol. 1, no. 4, pp. 223-228. http://dx.doi.org/10.1007/ s40475-014-0030-y.

BROOKER, S.J., NIKOLAY, B., BALABANOVA, D. and PULLAN, R.L., 2015. Global feasibility assessment of interrupting the transmission of soil-transmitted helminths: a statistical modelling study. The Lancet. Infectious Diseases, vol. 15, no. 8, pp. 941-950. http://dx.doi.org/10.1016/S1473-3099(15)70042-3. PMid:25886799.

BUSATO, M.A., DONDONI, D.Z., RINALDI, A.L. and FERRAZ, L., 2015. Parasitoses intestinais: o que a comunidade sabe sobre este tema? Revista Brasileira de Medicina de Família e Comunidade, vol. 10, no. 34, pp. 1-6. http://dx.doi.org/10.5712/ rbmfc10(34)922.

CARVALHO, S.A. and MALAFAIA, G., 2016. What adolescents know about intestinal parasitic infections: contributions to the promotion of health in high school. General Medicine: Open Access, vol. 4, no. 3, pp. 256. http://dx.doi.org/10.4172/23275146.1000256

CURI, N.H.A., PASCHOAL, A.M.O., MASSARA, R.L., SANTOS, H.A., GUIMARÃES, M.P., PASSAMANI, M. and CHIARELLO, A.G., 2016. Risk factors for gastrointestinal parasite infections of dogs living around protected areas of the Atlantic 
Forest: implications for human and wildlife health. Brazilian Journal of Biology, vol. 77, no. 2, pp. 388-395. http://dx.doi. org/10.1590/1519-6984.19515. PMid: 27533731.

DANSO-APPIAH, A., STOLK, W.A., BOSOMPEM, K.M., OTCHERE, J., LOOMAN, C.W.N., HABBEMA, J.D.F. and DE VLAS, S.J., 2010. Health seeking behaviour and utilization of health facilities for schistosomiasis-related symptoms in Ghana. PLoS Neglected Tropical Diseases, vol. 4, no. 11, pp. e867. http:// dx.doi.org/10.1371/journal.pntd.0000867. PMid:21072229.

DETOLLENAERE, J., DESMAREST, A.S., BOECKXSTAENS, P. and WILLEMS, S., 2018. The link between income inequality and health in Europe, adding strength dimensions of primary care to the equation. Social Science \& Medicine, vol. 201, pp. 103-110. http://dx.doi.org/10.1016/j.socscimed.2018.01.041. PMid:29471179.

DO, T.T., MØLBAK, K., PHUNG, D.C. and DALSGAARD, A., 2007. Helminth infections among people using wastewater and human excreta in peri-urban agriculture and aquaculture in Hanoi, Vietnam. Tropical Medicine \& International Health, vol. 12, no. 2, suppl. 2, pp. 82-90. http://dx.doi.org/10.1111/j.13653156.2007.01945.x. PMid:18005319.

DORNY, P., PRAET, N., DECKERS, N. and GABRIEL, S., 2009. Emerging food-borne parasites. Veterinary Parasitology, vol. 163, no. 3, pp. 196-206. http://dx.doi.org/10.1016/j.vetpar.2009.05.026. PMid:19559535.

FORSON, A.O., ARTHUR, I. and AYEH-KUMI, P.F., 2018. The role of family size, employment and education of parents in the prevalence of intestinal parasitic infections in school children in Accra. PLoS One, vol. 13, no. 2, pp. e0192303. http://dx.doi. org/10.1371/journal.pone.0192303. PMid:29415040.

GABE, C., ALMEIDA, D.R. and SIQUEIRA, L.O., 2009. Avaliação de eventos infecciosos oportunistas em crianças portadoras de leucemias. Revista Brasileira de Hematologia e Hemoterapia, vol. 31, no. 2, pp. 74-79. http://dx.doi.org/10.1590/ S1516-84842009005000017.

GÓRALSKA, K. and KURNATOWSKI, P., 2013. Parasites as etiological factors of nosocomial infections. Annals of Parasitology, vol. 59, no. 1, pp. 3-11. PMid:23829052.

GREENAWAY, E.S., LEON, J. and BAKER, D.P., 2012. Understanding the association between maternal education and use of health services in Ghana: exploring the role of health knowledge. Journal of Biosocial Science, vol. 44, no. 6, pp. 733-747. http:// dx.doi.org/10.1017/S0021932012000041. PMid:22377424.

GUPTA, K., BALA, M., DEB, M., MURALIDHAR, S. and SHARMA, D.K., 2013. Prevalence of intestinal parasitic infections in HIV-infect individuals and their relationship with immune status. Indian Journal of Medical Microbiology, vol. 31, no. 2, pp. 161-165. http://dx.doi.org/10.4103/0255-0857.115247. PMid:23867673.

JESKE, S., BIANCHI, T.F., MOURA, M.Q., BACCEGA, B., PINTO, N.B., BERNE, M.E.A. and VILLELA, M.M., 2018. Intestinal parasites in cancer patients in the South of Brazil. Brazilian Journal of Biology = Revista Brasileira de Biologia, vol. 78, no. 3, pp. 574-578. http://dx.doi.org/10.1590/15196984.175364. PMid:29185612.

LESSHAFFT, H., SCHUSTER, A., REICHERT, F., TALHARI, S., IGNATIUS, R. and FELDMEIER, H., 2011. Knowledge, attitudes, perceptions, and practices regarding cutaneous larva migrans in deprived communities in Manaus, Brazil. Journal of Infection in Developing Countries, vol. 6, no. 5, pp. 422-429. http://dx.doi.org/10.3855/jidc.2122. PMid:22610709.

LUDWIG, K.M., FREI, F., ALVARES FILHO, F. and RIBEIROPAES, J.T., 1999. Correlação entre condições de saneamento básico e parasitoses intestinais na população de Assis, Estado de São Paulo. Revista da Sociedade Brasileira de Medicina Tropical, vol. 32, no. 5, pp. 547-555. http://dx.doi.org/10.1590/ S0037-86821999000500013. PMid:10881090.

MARCOS, L.A. and GOTUZZO, E., 2013. Intestinal protozoan infections in the immunocompromised host. Current Opinion in Infectious Diseases, vol. 26, no. 4, pp. 295-301. http://dx.doi. org/10.1097/QCO.0b013e3283630be3. PMid:23806893.

MASAKU, J., MWENDE, F., ODHIAMBO, G., MUSUVA, R., MATEY, E., KIHARA, J.H., THUITA, I.G. and NJOMO, D.W., 2017. Knowledge, practices and perceptions of geohelminthes infection among parents of pre-school age children of coastal region, Kenya. PLoS Neglected Tropical Diseases, vol. 11, no. 3, pp. e0005514. http://dx.doi.org/10.1371/journal.pntd.0005514. PMid:28358802.

MELLO, D.A., PRIPAS, S., FUCCI, M., SANTORO, M.C. and PEDRAZZANI, E.S., 1988. Helmintoses intestinais: I. conhecimentos, atitudes e percepção da população. Revista de Saude Publica, vol. 22, no. 2, pp. 140-149. http://dx.doi.org/10.1590/ S0034-89101988000200010. PMid:3217729.

MORAES NETO, A.H.A., PEREIRA, A.P.M.F., ALENCAR, M.F.L., SOUZA-JÚNIOR, P.R.B., DIAS, R.C., FONSECA, J.G., SANTOS, C.P. and ALMEIDA, J.C.A. 2010. Prevalence of intestinal parasites versus knowledge, attitudes and practices of inhabitants of low-income communities of Campos dos Goytacazes, Rio de Janeiro State, Brazil. Parasitology Research, vol. 107, no. 2, pp. 295-307. http://dx.doi.org/10.1007/s00436010-1861-7. PMid:20407910.

MORAN, J.M., 1994. Interferências dos meios de comunicação no nosso conhecimento. Intercom - Revista Brasileira de Ciências da Comunicação, vol. 23, no. 2, pp. 38-49. http://dx.doi.org/10.1590/ rbcc.v17i2.844.

NYARANGO, R.M., ALOO, P.A., KABIRU, E.W. and NYANCHONGI, B.O., 2008. The risk of pathogenic intestinal parasite infections in Kisii Municipality, Kenya. BMC Public Health, vol. 8, no. 1, pp. 237. http://dx.doi.org/10.1186/14712458-8-237. PMid:18620608.

OLIVEIRA, S., SOUSA, L., BRASIL, J. and PIRES, C., 2013. Complicação de abscesso hepático em criança ribeirinha poliparasitada: um relato de caso e discussão sobre as condições de saneamento e acesso à saúde dessa população. Revista Brasileira de Medicina de Família e Comunidade, vol. 9, no. 31, pp. 213218. http://dx.doi.org/10.5712/rbmfc9(31)656.

OLSEN, A., THUAN, L.K., MURRELL, K.D., DALSGAARD, A., JOHANSEN, M.V. and DE, N.V., 2006. Cross sectional parasitological survey for helminth infections among fish farmers in Nghe An province, Vietnam. Acta Tropica, vol. 100, no. 3, pp. 199-204. http://dx.doi.org/10.1016/j.actatropica.2006.10.010. PMid:17141724.

PACHECO, F.T.F., SILVA, R.K.N.R., MENDES, A.V.A., MENDONÇA, N., RIBEIRO, T.C.M., SOARES, N.M. and TEIXEIRA, M.C.A., 2014. Infecção por Giardiaduodenalise outros enteroparasitos em crianças com câncer e crianças de creche em Salvador, Bahia. Revista de Ciências Médicas e Biológicas, vol. 13, no. 3, pp. 280-286. http://dx.doi.org/10.9771/ cmbio.v13i3.12932. 
PEDRAZZANI, E.S., MELLO, D.A., PIZZIGATTI, C.P. and BARBOSA, C.A.A., 1990. Aspectos educacionais da intervenção em helmintoses intestinais, no subdistrito de Santa Eudóxia, Município de São Carlos - SP. Cadernos de Saude Publica, vol. 6, no. 1, pp. 74-85. http://dx.doi.org/10.1590/S0102-311X1990000100008.

PIO, I.D.S.L., LAVOR, A.L., DAMASCENO, C.M.D., MENEZES, P.M.N., SILVA, F.S. and MAIA G.L.A., 2018. Traditional knowledge and uses of medicinal plants by the inhabitants of the islands of the São Francisco river, Brazil and preliminary analysis of Rhaphiodon echinus (Lamiaceae). Brazilian Journal of Biology, vol. 79, no. 1, pp. 87-99. http:// dx.doi.org/10.1590/1519-6984.177447.

RIVERO, M.R., SALAS, M.M., VALENTE, R., NORES, M.J., DE ANGELO, C., ARRABAL, J., COSTA, S. and SALOMÓN, O.D., 2017. Prevention of intestinal parasites in a tri-border area of Latin America: children perceptions and an integral health education strategy. Zoonoses and Public Health, vol. 64, no. 8, pp. 673-683. http://dx.doi.org/10.1111/zph.12365. PMid:28590086.

ROSSI, A. and COUTURIER, M.R., 2016. Cryptosporidiosis in a severely immunocompromised HIV patient. Journal of Clinical Microbiology, vol. 54, no. 9, pp. 2219-2221. PMid: 27578161.

SANCHEZ, A.L. and FAIRFIELD, T., 2003. Using electronic technology for Taenia solium education: educating the educators. Acta Tropica, vol. 87, no. 1, pp. 165-170. http://dx.doi.org/10.1016/ S0001-706X(03)00040-8. PMid:12781392.

SANTOS, M.B., OLIVEIRA, M., BARRETO, A.S., PEREIRA, J.M., COSTA, M.C.F.S. and ARAÚJO, K.C.G.M., 2012. Evaluation of knowledge about and an educational intervention with students of a municipal school in Santana do Ipanema, state of Alagoas. Scientia Plena, vol. 8, no. 3, pp. 1-7.

SCHÄR, F., TROSTDORF, U., GIARDINA, F., KHIEU, V., MUTH, S., MARTI, H., VOUNATSOU, P. and ODERMATT, P., 2013. Strongyloidesstercoralis: global distribution and risk factors. PLoS Neglected Tropical Diseases, vol. 7, no. 7, pp. e2288. http://dx.doi.org/10.1371/journal.pntd.0002288. PMid:23875033.

SILVA, J.C., FURTADO, L.F., FERRO, T.C., BEZERRA, K.C., BORGES, E.P. and MELO, A.C.F.L., 2011. Parasitismo por Ascaris lumbricoides e seus aspectos epidemiológicos em crianças do Estado do Maranhão. Revista da Sociedade Brasileira de Medicina Tropical, vol. 44, no. 1, pp. 100-102. http://dx.doi. org/10.1590/S0037-86822011000100022. PMid:21340418.

SILVA, T.V. and LEDA, L.R., 2013. Intervenções educativas sobre parasitoses intestinais: aplicação de um jogo para alunos do Ensino Fundamental. Revista Acadêmica Saúde \& Ambiente, vol. 7, no. 2, pp. 23-37.

SIQUEIRA, M.P., AZEVEDO, E.P., ALMEIDA, E.M., MATOS, J.S., RODRIGUES, A.R., SCARABELLI, S.C., PILOTTO, T.P., FREITAS, J.T., BARBOSA, A.S., MATTOS, D.P.B.G., BASTOS, O.M.P. and UCHÔA, C.M.A., 2016. Conhecimentos de escolares e funcionários da Rede Pública de Ensino sobre as parasitoses intestinais. Revista do Instituto Adolfo Lutz, vol. 75, pp. 1711

SIQUEIRA, R.V. and FIORINI, J.E., 1999. Conhecimentos e procedimentos de crianças em idade escolar frente às parasitoses intestinais. Revista da Universidade de Alfenas, vol. 5, pp. 215-220.

TANNER, S., CHUQUIMIA-CHOQUE, M.E., HUANCA, T., MCDADE, T.W., LEONARD, W.R. and REYES-GARCIA, V., 2011. The effects of local medicinal knowledge and hygiene on helminth infections in an Amazonian society. Social Science \& Medicine, vol. 72, no. 5, pp. 701-709. http://dx.doi.org/10.1016/j. socscimed.2010.12.012. PMid:21306810.

VENTO, S. and CAINELLI, F., 2003. Infections in patients with cancer undergoing chemotherapy: etiology, prevention, and treatment. The Lancet Oncology, vol. 4, no. 10, pp. 595-604. http:// dx.doi.org/10.1016/S1470-2045(03)01218-X. PMid:14554236.

VIDAL, S.F., TOLOZA, L.M. and CANCINO, B.F., 2010. Evolución de la prevalência de enteroparasitos em laciudad de Talca, RegióndelMaule, Chile. Revista Chilena de Infectologia, vol. 17, no. 4, pp. 336-340. http://dx.doi.org/10.4067/S071610182010000500009 .

WRIGHT, S.G., 2012. Protozoan infections of the gastrointestinal tract. Infectious Disease Clinics, vol. 26, no. 2, pp. 323-339. http://dx.doi.org/10.1016/j.idc.2012.03.009. PMid:22632642. 